\title{
Natural genetic transformation of Pseudomonas stutzeri in a non-sterile soil
}

\author{
Johannes Sikorski, Stefan Graupner, Michael G. Lorenz \\ and Wilfried Wackernagel
}

Genetik, Fachbereich Biologie, Carl von Ossietzky Universität Oldenburg, Postfach 2503 D-26111 Oldenburg, Germany
Author for correspondence: Michael G. Lorenz. Tel: +49 441798 2937. Fax: +49 4417983250. e-mail: lorenz@biologie.uni-oldenburg.de

\begin{abstract}
Natural transformation of the soil bacterium Pseudomonas stutzeri JM300 in a non-sterile brown earth microcosm was studied. For this purpose, the microcosm was loaded with purified DNA (plasmid or chromosomal DNA, both containing a high-frequency-transformation marker, his', of the P. stutzeri genome), the non-adsorbed DNA was washed out with soil extract and then the soil was charged with competent cells (his-1). Both chromosomal and plasmid transformants were found among the $P$. stutzeri cells recovered from the soil. The number of plasmid transformants increased in a linear fashion with the amount of DNA added [10-600 $\left.\mathrm{ng}(0.7 \mathrm{~g} \mathrm{soil)})^{-1}\right]$. The observed efficiency of transformation, the time course of transformant formation and the complete inhibition of transformation by DNase I, when added to the soil, were similar to that seen in optimized transformations in nutrient broth. Addition of cells as late as $\mathbf{3} \mathbf{d}$ after loading the soil with plasmid DNA still yielded $3 \%$ of the initial transforming activity. This suggests that nucleases indigenous to the soil destroyed the transforming DNA, but at a rate allowing considerable DNA persistence. Transformants were also obtained when intact P. stutzeri cells were introduced into the soil to serve as plasmid DNA donors. Apparently, DNA was released from the cells, adsorbed to the soil material and subsequently taken up by recipient cells. The results indicate that competent cells of $P$. stutzeri were able to find access to and take up DNA bound on soil particles in the presence of micro-organisms and DNases indigenous to the soil.
\end{abstract}

Keywords: natural transformation, soil, Pseudomonas stutzeri, DNA release, DNA degradation

\section{INTRODUCTION}

A current topic of microbial ecology and evolution is genetic adaptation of populations to environmental changes and the mechanisms involved. Mutagenesis imposed by DNA-damaging agents (e.g. UV light) or occurring spontaneously in dividing as well as in resting cells with the result of the generation of genetic variants is considered a basis for adaptation (Arber, 1995; Taddei et al., 1995; Travisano et al., 1995). Horizontal gene transfer has been discussed as another process for the creation of genetic diversity in bacterial populations and

Abbreviations: $\mathrm{Cm}$, chloramphenicol; $\mathrm{Km}$, kanamycin; Nal, nalidixic acid; Rif, rifampicin; Sm, streptomycin; his-1, histidine auxotrophy allele.

The GenBank accession number for the nucleotide sequence reported in this paper is AF010189. communities (Maynard Smith et al., 1991, 1993; Mazodier \& Davies, 1991; Cohan, 1995; Lorenz \& Wackernagel, 1996). Further interest in the horizontal exchange of genes comes from considerations about the safety of genetically engineered organisms when released into the environment with respect to the potential dissemination of recombinant DNA into the microflora of habitats such as soil (Stotzky \& Babich, 1986; Tiedje et al., 1989; Doyle et al., 1995). The occurrence of genetic interactions among bacteria in the environment by gene transfer mechanisms including conjugation, transduction and transformation has been the topic of several reviews (e.g. Kokjohn, 1989; Stotzky et al., 1990; Mazodier \& Davies, 1991; Lorenz \& Wackernagel, 1994, 1996; Thomas et al., 1994; Goodman et al., 1994; Lorenz, 1998). So far, most information is available on conjugation and only a few studies have been concerned 
with transduction and transformation in the environment. Here we have addressed the question of whether natural genetic transformation can occur in soil, one of the most complex environments in terms of its physical/chemical structure and its microbial community (for a review, see Stotzky, 1989).

Transformation is the active uptake of extracellular DNA by bacterial cells that have developed the physiological state of competence, followed by the integration of the DNA into the recipient genome by homologous recombination and the expression of newly gained genes (for reviews, see Dubnau, 1991, 1993; Lorenz \& Wackernagel, 1994; Solomon \& Grossman, 1996). In the experiments described in this paper the Gramnegative soil bacterium Pseudomonas stutzeri JM300 (Carlson et al., 1983) was used. This organism can be transformed by chromosomal and plasmid DNA both in vitro (Carlson et al., 1983, 1984) and in soil extracts (Lorenz \& Wackernagel, 1991, 1992). DNA competition experiments with this strain showed that heterologous DNA is discriminated during uptake (Carlson et al., 1983; Lorenz \& Wackernagel, 1990). This feature resembles that of pathogenic Neisseria gonorrhoeae and Haemophilus influenzae which selectively take up DNA of their own species on the basis of recognition of a species-specific nucleotide sequence on the donor DNA (Lorenz \& Wackernagel, 1994). Pseudomonas stutzeri JM300 can develop competence in nutrient-amended soil extracts to levels similar to those obtained under standard broth cultivations. Competence is further stimulated under carbon-, nitrogen- and phosphoruslimited conditions which bacteria may frequently encounter in soil (Lorenz \& Wackernagel, 1991, 1992). Here a histidine-requiring mutant of $P$. stutzeri JM300 was used to study transformation in a microcosm containing a non-sterile loamy sand. The experiments focussed on the following questions: (i) are competent cells able to find access to and take up DNA in the soil; (ii) how long does the transforming activity of DNA persist after the DNA has been added to the soil; and (iii) do cells of $P$. stutzeri JM300 added to the soil liberate transforming DNA and is that DNA available to competent cells? As a donor DNA, a plasmid with a fragment of the $P$. stutzeri genome was constructed that complemented the his-1 mutation which was shown to be an amber mutation. Either purified plasmid DNA or donor cells carrying the plasmid were introduced into the soil microcosm, followed by extensive washing of the soil so that only particle-bound DNA remained for uptake by added competent $P$. stutzeri cells.

\section{METHODS}

Strains, plasmids and DNA isolation. Pseudomonas stutzeri JM375 (wild-type) was used as a source for the preparation of transforming chromosomal DNA. Strains BA155 [his-1 Rif ${ }^{\mathrm{R}}$ $\mathrm{Nal}^{\mathrm{R}} \mathrm{Km}^{\mathrm{R}} \mathrm{LacZ}^{+}$(Tn5::lacZ)] and JM302 (his-1; pSI1) were used as a recipient and as a source for the isolation of transforming plasmid DNA, respectively. JM302(pSI1) was also used as a donor in soil microcosm experiments. All strains are derivatives of $P$. stutzeri JM300 (Carlson et al., 1983).
Plasmid pSI1 $\left(\mathrm{Sm}^{\mathbf{R}} \mathrm{His}^{+} ; 10 \mathrm{~kb}\right)$ was constructed as follows. Plasmid pWI90 (16.8 kb), complementing the his-1 auxotrophy of BA155, was isolated from a JM375 chromosomal gene bank, constructed by partial Pst I digestion and ligation into PstI-digested RSF1010 (Bagdasarian et al., 1981). From pWI90, a $2.3 \mathrm{~kb}$ PstI DNA fragment was subcloned into RSF1010, giving rise to pSI1, and into PstI-digested pBluescript (Stratagene) for sequencing. Cloning and nucleotide sequencing (using the GATC 1500 apparatus, Gesellschaft für Analyse-Technik und Consulting) were done according to standard procedures (Sambrook et al., 1989).

DNA of pSI 1 and pKT210 $\left(\mathrm{Sm}^{\mathrm{R}} \mathrm{Cm}^{\mathrm{R}} ; 11.4 \mathrm{~kb}\right)$, a derivative of RSF1010, was isolated by the rapid boiling method (Holmes \& Quigley, 1981) and further purified using the Qiagen plasmid purification kit.

Competence. For preparation of highly competent cultures $\left(0.7-1 \cdot 1 \times 10^{-4} \mathrm{His}^{+}\right.$transformants per viable count at $5 \mu \mathrm{g}$ chromosomal DNA ml ${ }^{-1}$; viable count, approx. $3 \times 10^{9} \mathrm{ml}^{-1}$ ), BA155 was cultured in LB-glucose medium (Carlson et al., 1983), frozen at $-80^{\circ} \mathrm{C}$, thawed and incubated at $37^{\circ} \mathrm{C}$ for $5 \mathrm{~h}$ as described previously (Lorenz \& Wackernagel, 1990).

Media. For selection of transformants $\left(\mathrm{His}^{+}\right)$, minimal pyruvate medium (Lorenz \& Wackernagel, 1991) containing rifampicin $\left(20 \mu \mathrm{g} \mathrm{ml}^{-1}\right)$, nalidixic acid $\left(50 \mu \mathrm{g} \mathrm{ml}^{-1}\right)$ and cycloheximide $\left(50 \mu \mathrm{g} \mathrm{ml}^{-1}\right)$ for suppression of growth of microorganisms indigenous to the soil (bacteria and fungi), was used (termed M7P). Viable counts of $P$. stutzeri BA155 were determined by plating on M7P plus histidine $\left(40 \mu \mathrm{g} \mathrm{ml}^{-1}\right)$.

Transformation procedure in liquid culture. For transformation in LB-glucose broth, $20 \mu \mathrm{l}$ pSI1 DNA (1-1000 ng) was mixed with $180 \mu \mathrm{l}$ of a competent culture and incubated at $37^{\circ} \mathrm{C}$ for $90 \mathrm{~min}$. Thereafter, DNA uptake was terminated by adding DNase I solution (final concentration, $10 \mu \mathrm{g} \mathrm{ml}^{-1}$; $15 \mathrm{mM} \mathrm{MgCl}, 1 \mathrm{mM} \mathrm{CaCl}{ }_{2}$ ) and incubation at $37^{\circ} \mathrm{C}$ for $10 \mathrm{~min}$. Aliquots (usually $100 \mu \mathrm{l}$ ) of undiluted or diluted (in $50 \mathrm{mM}$ potassium phosphate buffer, $\mathrm{pH} 7 \cdot 2$ ) cell suspensions were plated on M7P or M7P plus histidine for the determination of transformant and viable counts, respectively. Plates were incubated at $37^{\circ} \mathrm{C}$ for $2 \mathrm{~d}$.

Soil and soil extract. The brown earth used was a loamy sand soil $(82.9 \%$ sand, $12.2 \%$ silt, $4.9 \%$ clay) collected from the Ap-horizon from an agricultural field near Braunschweig, Germany (courtesy of Dr C. Tebbe, Institut für Bodenbiologie, Braunschweig). The soil was air-dried at $23^{\circ} \mathrm{C}$ for $12 \mathrm{~d}$, sieved ( $2 \mathrm{~mm}$ mesh size) and stored in the dark at $23^{\circ} \mathrm{C}$ until use. The residual moisture content was $2 \%(\mathrm{w} / \mathrm{w})$.

The procedure for the preparation of an aqueous extract from the soil was the same as described previously (Lorenz \& Wackernagel, 1991). The heated extract $\left(80^{\circ} \mathrm{C}, 20 \mathrm{~min}\right)$ was filtered (cellulose acetate, $200 \mathrm{~nm}$ pore size, Schleicher \& Schuell) and stored at $4{ }^{\circ} \mathrm{C}$ until use.

Soil microcosm. Microcosm experiments were carried out in the flow-through glass column system described previously (Lorenz \& Wackernagel, 1987). To retain small particles of soil material, columns were closed with a filter paper (no. 595, Schleicher \& Schuell) and covered with an $8 \mathrm{~mm}$ layer of chemically pure sand (Merck). Any potential DNA binding sites on glass or on the sand were saturated by adding $1 \mathrm{ml}$ of a calf thymus DNA solution $\left(600 \mu \mathrm{g} \mathrm{ml}^{-1}\right.$ in $10 \mathrm{mM}$ Tris $/ \mathrm{HCl}$, pH $8 \cdot 0,1 \mathrm{mM}$ EDTA, $200 \mathrm{mM} \mathrm{MgCl}_{2}$ ) to the columns which were then incubated at $23{ }^{\circ} \mathrm{C}$ for $2 \mathrm{~h}$. The columns were rinsed twice with $1 \mathrm{ml} 10 \mathrm{mM}$ Tris $/ \mathrm{HCl}, \mathrm{pH} 8.0,1 \mathrm{mM}$ EDTA, $200 \mathrm{mM} \mathrm{MgCl}$ to remove non-adsorbed DNA and dried at 
$37^{\circ} \mathrm{C}$ overnight. Columns were filled with $0.7 \mathrm{~g}$ air-dried soil material and $300 \mu \mathrm{l}$ sterile deionized water (corresponding to the interstitial volume of the soil) was added. After incubation for $8 \mathrm{~d}$ at $23^{\circ} \mathrm{C}$, allowing growth of indigenous microorganisms and production of extracellular nucleases (Blum et al., 1998), the equilibrated microcosm was used for transformation experiments.

Transformation in the soil microcosm. Chromosomal or plasmid DNA (usually $1 \mu \mathrm{g}$ ) dissolved in $300 \mu \mathrm{l}$ soil extract was added on top of the equilibrated soil in the microcosm. After drainage of the solution into the soil, the microcosm was incubated at $23^{\circ} \mathrm{C}$ usually for $1 \mathrm{~h}$ to allow DNA adsorption to the soil material. Non-adsorbed DNA was then removed by washing the columns with $6 \mathrm{ml}$ soil extract using a high precision pump (LKB; flow rate, $12 \mathrm{ml} \mathrm{h}^{-1}$ ). Applying this procedure and $\left[{ }^{3} \mathrm{H}\right]$ thymidine-labelled chromosomal or plasmid DNA (both $2.3 \times 10^{4}$ d.p.m. $\mu \mathrm{g}^{-1}$ ), the amount of DNA bound on soil particulates was calculated from the difference in the radioactivity added and the radioactivity washed out of the column.

For loading of a soil column with competent BA155, cells were harvested from the competent culture $(1.5 \mathrm{ml}$; viable count, approx. $3 \times 10^{9} \mathrm{ml}^{-1}$ ) by centrifugation, washed once with 1 vol. soil extract and finally resuspended in $450 \mu$ l soil extract. The cell suspension $(300 \mu \mathrm{l})$ was added to the column and incubation continued $\left(23^{\circ} \mathrm{C}\right.$, usually for $\left.4 \mathrm{~h}\right)$. Thereafter, the contents of the column were transferred to a tube with $1 \mathrm{ml}$ broth containing DNase I $\left(1 \mathrm{mg} \mathrm{m}^{-1}\right)$. After incubation at $37{ }^{\circ} \mathrm{C}$ for $1 \mathrm{~h}$ (to allow termination of DNA uptake in soil and gene expression, see below), the column material, including BA155 cells, was sedimented for $2 \mathrm{~min}$ at 13000 r.p.m. (Biofuge, Heraeus) and the pellet resuspended in $0.7 \mathrm{ml}$ buffer ( $50 \mathrm{mM}$ potassium phosphate, $\mathrm{pH} 7 \cdot 2$ ) by hand shaking of the tube. The suspension was serially diluted in buffer and plated for the determination of BA155 $\mathrm{His}^{+}$transformants and viable count as described for transformation in liquid culture (see above), except that $200 \mu \mathrm{l}$ of sample was mixed with $3 \mathrm{ml}$ liquid $M 7 P$ top-agar $\left(0.5 \%\right.$ agar; $\left.55^{\circ} \mathrm{C}\right)$ before plating. Incubation was at $37^{\circ} \mathrm{C}$ for $3 \mathrm{~d}$. To test for the unselected markers, $\mathrm{Km}^{\mathrm{R}}$ and $\mathrm{LacZ}^{+}$(blue appearance), colonies grown on M7P were streaked on M7P plus kanamycin $\left(60 \mu \mathrm{g} \mathrm{ml}^{-1}\right)$ and X-Gal $(0.008 \%, \mathrm{w} / \mathrm{w})$. $\mathrm{His}^{+}$colonies were tested for the presence of pSI1 by streaking on M7P plus streptomycin $\left(1 \mathrm{mg} \mathrm{ml}^{-1}\right)$ and clone analysis. Recovery of BA155 was efficient: of the viable count introduced, $54 \%$ was found by plating soil suspensions on M7P plus histidine (all colonies were $\mathrm{Km}^{\mathrm{I}}$ and $\mathrm{LacZ}^{+}$). When competent BA155 cells together with pSI1 DNA were mixed with the soil in broth and immediately afterwards DNase I was added (incubation and plating as above), transformants were never found, showing that DNase I incubation led to complete inactivation of transforming pSI1 DNA before cells were plated (data not shown).

The following experiment was performed to test whether transforming DNA desorbed from the solid/liquid interphases during the period of transformation in the soil. A suspension of competent cells in soil extract was incubated at $23^{\circ} \mathrm{C}$ for $4 \mathrm{~h}$, sedimented and sterile-filtered. The treated extract was then added to a microcosm containing soil-particle-bound pSI1 DNA $(0.56 \mu \mathrm{g})$ and incubated at $23^{\circ} \mathrm{C}$ for $4 \mathrm{~h}$. Thereafter, the interstitial soil liquid $(300 \mu \mathrm{l})$ was recovered and used for transformation of competent $P$. stutzeri BA155 cells. For this, $180 \mu \mathrm{l}$ of recovered soil liquid was mixed with $20 \mu \mathrm{l} 10$-fold concentrated (centrifugation) competent BA155 cells in soil extract and incubated at $37^{\circ} \mathrm{C}$ for $90 \mathrm{~min}$. The numbers of transformants and viable count were determined as above.
The procedure for recovery of the interstitial soil liquid was the same as described previously (Lorenz et al., 1988).

For the study of DNA release and uptake in soil, stationary phase cells of the plasmid donor strain, JM302(pSI1), were washed twice with soil extract to remove extracellular plasmid DNA. Cells in soil extract were then added to soil microcosms and incubated at $23^{\circ} \mathrm{C}$ for $2 \mathrm{~h}$. Thereafter, columns were washed and competent BA155 cells suspended in soil extract were added. Loading of soil microcosms with donor cells, washing with soil extract, subsequent loading with competent BA155, incubation in broth in the presence of DNase I and plating were performed as described for the transformation experiments involving free DNA (see above). In some experiments, microcosms were loaded with the donor strain and frozen at $-20^{\circ} \mathrm{C}$. After $30 \mathrm{~min}$, the microcosms were thawed at $23^{\circ} \mathrm{C}$. The freezing and thawing procedure was repeated once before the columns were washed with soil extract and charged with competent BA155.

Statistics. Experiments were repeated at least once. In those cases in which experiments were repeated twice or more, the mean of the results and SEM were calculated. Student's $t$-test was used for calculation of significant differences between means.

\section{RESULTS}

\section{The genetic system}

In most experiments plasmid DNA was used as the transforming DNA. Using plasmid DNA has the following advantages: (i) the DNA molecules are equal in size allowing defined conditions during DNA adsorption, DNA degradation and transformation studies; (ii) the demonstration of the physical presence of plasmids in transformed cells is a direct proof, in addition to phenotypic traits, of transformation events; (iii) each DNA molecule contains the selective markers. The plasmid used (pSI1) had an $\mathrm{Sm}^{\mathrm{R}}$ determinant and a region of homology to the $P$. stutzeri genome which, besides providing complementation of the his-1 mutation of the recipient cells (BA155), greatly enhanced the efficiency of transformation (see next section). The nucleotide sequence of the homology fragment $(2180 \mathrm{bp}$ ) contained one complete ORF of $1188 \mathrm{bp}$. So far, database searches have not shown amino acid sequence similarity to any known gene involved in histidine biosynthesis. Determination of the nucleotide sequence of a $596 \mathrm{bp}$ PCR amplification product (using a 20-mer primer/reverse primer pair at positions 265 and 861 of the ORF, respectively) from the chromosome of JM302 revealed that the his-1 mutation is the result of a $\mathrm{C} \rightarrow \mathrm{T}$ substitution (position 642 of the homologous fragment) leading to an amber triplet.

\section{Characterization of plasmid transformation of P. stutzeri}

To study the effect of a region of homology to the chromosome on plasmid transformation, transformation frequencies obtained with pSI 1 and pKT210 DNA at various concentrations were compared (Fig. 1). With pKT210, the dependence of the transformation frequency $\left(\mathrm{Sm}^{\mathrm{R}}\right)$ on the amount of plasmid DNA followed 


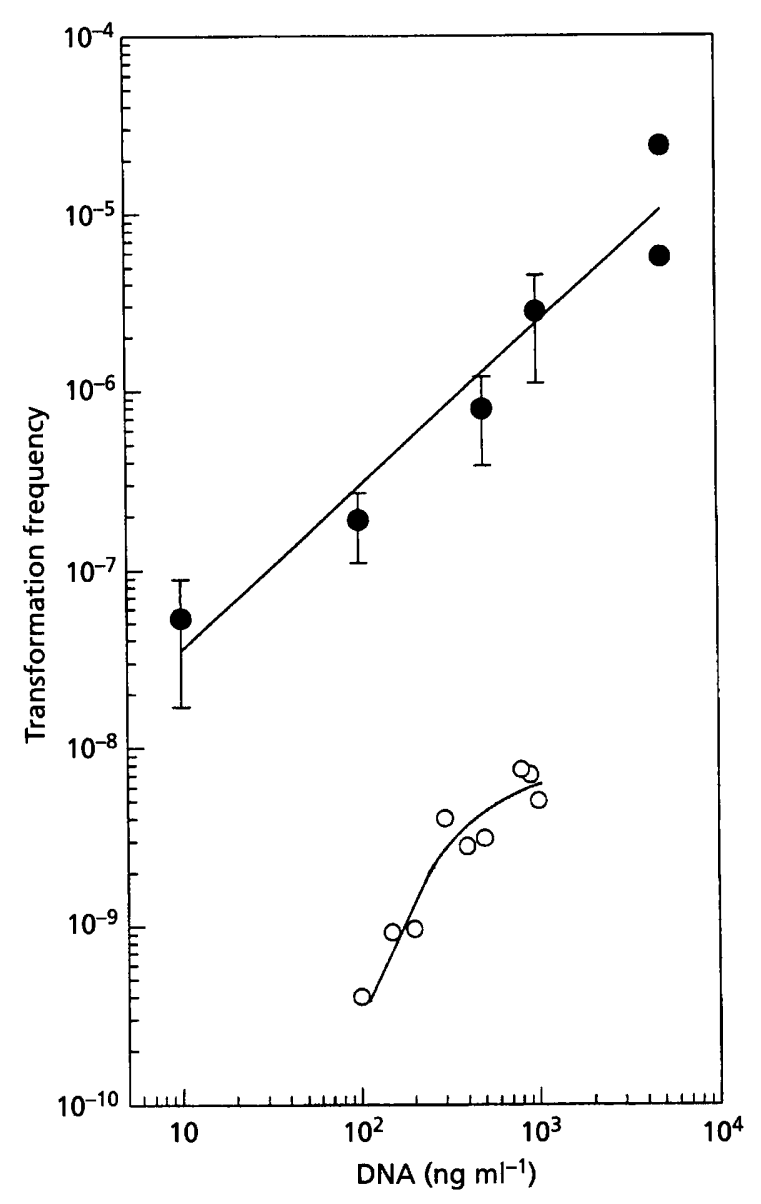

Fig. 1. Dependence of the frequency of transformation of P. stutzeri BA155 in broth on the concentration of pSI1 DNA (O) or pKT210 DNA (O). Selection was for histidine prototrophy (pSI1) or streptomycin resistance (pKT210). Bars indicate the SD $(n=3)$.

a two-hit mechanism (the tangent of the inclination angle was determined to be $2 \cdot 05$ ), i.e. two plasmid molecules were required to form a transformant. Transformation with pKT210 was very inefficient, giving a transformation frequency of only $5 \times 10^{-9}$ at a DNA concentration of $1 \mu \mathrm{g} \mathrm{ml}^{-1}$ (Fig. 1). Transformation by pSI1 was much more efficient and followed a one-hit mechanism (the tangent of the inclination angle was determined to be 0.92 ), i.e. a single pSI 1 molecule sufficed to generate a $\mathrm{His}^{+}$transformant. This one-hit mechanism of plasmid transformation is comparable to that of chromosomal DNA (the tangent of the inclination angle was determined to be 0.97 ; Lorenz et al., 1998) which is integrated into the recipient genome following DNA uptake (Dubnau, 1993; Lorenz \& Wackernagel, 1994). It is concluded that the enhanced transformation efficiency by pSI 1 was effected by the interaction of the plasmid via its homologous region with the chromosome of $P$. stutzeri.

Further analysis indicated two types of transformants obtained by homology-facilitated plasmid transform- ation (215 clones tested). Most of the $\mathrm{His}^{+}$transformants were without a plasmid $\left(\mathrm{Sm}^{\mathrm{S}} ; 98 \%\right)$, the remainder were $\mathrm{Sm}^{\mathrm{R}}$ and contained pSI1. These results can be explained by a model for homology-facilitated plasmid transformation described for Bacillus subtilis (Canosi et al., 1981) and Streptococcus pneumoniae (Lopez et al., 1982). The model takes into account the double-strand breakage of plasmid molecules during uptake and the transport of a DNA single strand into the cell. Upon breakage in the vector part, the homologous region of pSI1 can be assimilated into the recipient genome. In this way, plasmid-free $\mathrm{His}^{+}$transformants arise (major fraction). Breakage within the region of homology is assumed to allow invasion of the recipient genome by both ends of the linear single strand. Subsequent repair DNA synthesis, formation of a circular single-stranded molecule and synthesis of the complementary strand is thought to lead to the reconstitution of an intact plasmid (Canosi et al., 1981). This can complement the his-1 allele of the recipient cell and provide streptomycin resistance (minor faction). Proof of the physical interaction between the homologous regions of the plasmid and the chromosome in P. stutzeri JM300 has been obtained by showing that during repair DNA synthesis nucleotide sequences of the host chromosome were copied into the reconstituting plasmid (Lorenz et al., 1998; J. Barklage, M. G. Lorenz \& W. Wackernagel, unpublished).

\section{Transformation in the soil microcosm}

For the microcosm studies, non-sterile soil was used exclusively. Treatments for sterilization of soil such as irradiation, fumigation or heating are known to drastically alter the chemical and physical properties of soil which, for instance, result in the liberation of large amounts of organic carbon (Lynch, 1982). For this reason, sterilized soil was not included in the study. Microcosms containing the non-sterile brown earth to which either chromosomal or pSI1 DNA was bound were loaded with competent $P$. stutzeri BA155 and incubated at $23{ }^{\circ} \mathrm{C}$ for $4 \mathrm{~h}$. Significant differences of the frequency of $\mathrm{His}^{+}$counts between experiments (DNA added to soil) and controls (no DNA added to soil; DNase I-treated DNA in soil) were considered as an indication of transformation in the soil. In experiments with PSI1 DNA added to the soil, the presence of the plasmid in $\mathrm{His}^{+}$clones was taken as direct proof for transformation. There is reason to conclude that the counts of transformants obtained in the experiments described below relied on primary transformation events and not on growth of siblings of transformants in the soil: because of the limitation of sources of carbon/ energy, phosphorus and nitrogen, P. stutzeri JM300 cells do not grow under conditions simulating the soil environment (soil extract; Lorenz \& Wackernagel, 1992) or when directly added to non-sterile soil (data not shown).

Table 1 shows that the frequency of $\mathrm{His}^{+}$cells was 46 times higher when the soil microcosm was loaded with chromosomal DNA than with no DNA added (level of 
Table 1. Transformation of $P$. stutzeri BA155 in the nonsterile soil microcosm

\begin{tabular}{|lcc|}
\hline DNA* & $\begin{array}{c}\mathbf{1 0}^{6} \times \text { Frequency of } \text { His }^{+} \\
\text {count } \pm \text { SD }\end{array}$ \\
\hline Chromosomal & & $0 \cdot 26 \pm 0 \cdot 11(n=4)$ \\
pSI1 & -DNase I & $2 \cdot 4 \pm 2 \cdot 0(n=7)$ \\
& +DNase I $\dagger$ & $0.0036 \pm 0.0021(n=5)$ \\
None & & $0.0056 \pm 0.0022(n=11)$ \\
\hline
\end{tabular}

* Chromosomal DNA $(0.74 \mu \mathrm{g})$ and pSI1 DNA $(0.57 \mu \mathrm{g})$ bound on $0 \cdot 7 \mathrm{~g}$ soil.

tpSI1-DNA-loaded soil was incubated in the presence of DNase I at $23^{\circ} \mathrm{C}$ for 60 min before competent cells were added.

spontaneous reversion frequency). With pSI1 DNA bound on soil material, the frequency of $\mathrm{His}^{+}$cells obtained in the soil microcosm was even higher. The results indicate that transformation by chromosomal and plasmid DNA proceeded in the non-sterile soil. This conclusion was further supported by the findings that (i) among the $\mathrm{His}^{+}$transformants $6 \%$ were $\mathrm{Sm}^{\mathrm{R}}$ and contained pSI1 (299 clones tested) and (ii) the frequency of $\mathrm{His}^{+}$counts was at the same level as the spontaneous reversion frequency when DNase I was added to pSI1DNA-loaded soil before competent cells were introduced (Table 1).

An experiment was performed to test whether transformation resulted from uptake of DNA desorbing from the solid/liquid interphases into the soil liquid or of DNA bound to particulates. For this purpose, the soil microcosm containing particle-bound pSI1 DNA $\left[0.56 \mu \mathrm{g}(0.7 \mathrm{~g} \text { soil })^{-1}\right]$ was incubated for $4 \mathrm{~h}$ before the soil liquid was recovered and used for transformation of competent BA155. The results showed that only $10 \%$ of the overall transformation frequency in the soil (see Table 1) was detected in the soil liquid. This was interpreted as an indication that $P$. stutzeri cells were transformed in soil mostly by particle-bound pSI1 DNA.

To study the kinetics of transformant formation in soil, pSI1-DNA-loaded microcosms were incubated with competent BA155 for various periods before the transformation process was terminated by DNase I treatment. Transformants were detected after $30 \mathrm{~min}$ (transformation frequency $4 \times 10^{-7}$ ). The transformation frequency increased subsequently to the maximum frequency generally obtained after $2-4 \mathrm{~h}\left(6 \times 10^{-6}\right)$.

\section{Dependence of transformation on amount of DNA in the soil}

A linear response of the transformation frequency to increasing DNA amounts in the soil microcosm was observed (Fig. 2). The tangent of the inclination angle in Fig. $2(\tan \alpha=0.96)$ is indicative of a one-hit mechanism. Transformants were reliably detected at $10 \mathrm{ng}$ pSI 1 DNA added to the microcosm. It is concluded that competent $P$. stutzeri cells readily found access to and took up the plasmid DNA in the soil microcosm.

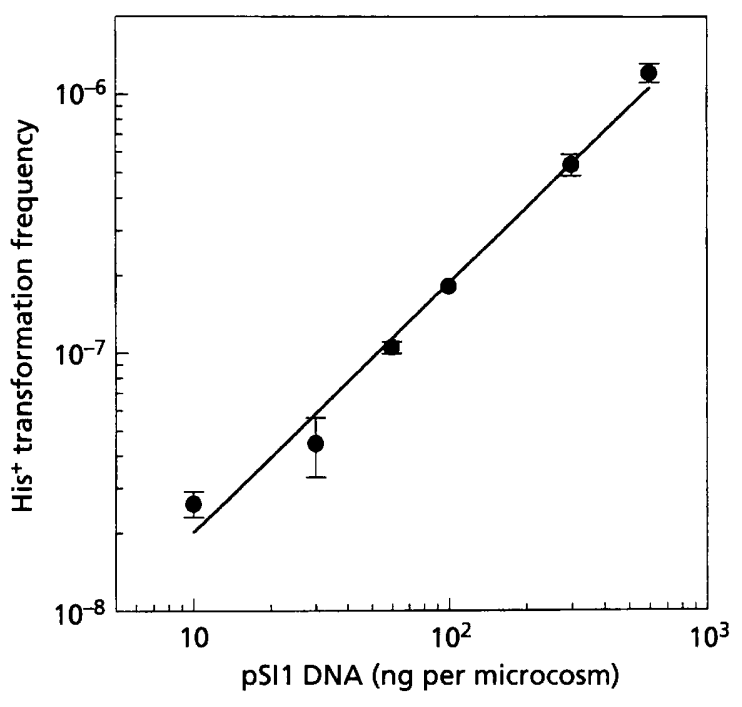

Fig. 2. Dependence of the transformation frequency of $P$. stutzeri BA155 on the amount of PSI1 DNA present in nonsterile soil microcosms. The amounts of DNA indicated were loaded on the soil microcosms. Non-adsorbed DNA was washed out with soil extract after $60 \mathrm{~min}$ at $23^{\circ} \mathrm{C}$ before competent cells were added. The mean of two independent experiments and the data range of the duplicate analyses (bars) are shown.

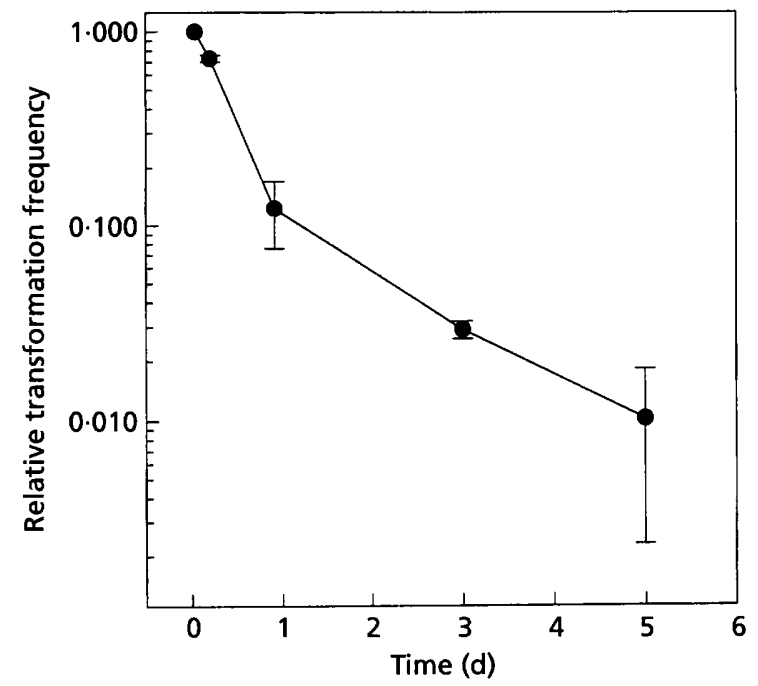

Fig. 3. Decay of the transforming activity of pSI1 DNA in nonsterile soil microcosms over time. The mean of two independent experiments and the data range of the duplicate analyses (bars) are shown. A relative transformation of $100 \%$ corresponds to a transformation frequency of $6.1 \times 10^{-7} \pm 3.9 \times 10^{-7}$.

\section{Fate of transforming DNA in the soil}

Plasmid pSI1 DNA was incubated in the microcosm for periods from 1 to $120 \mathrm{~h}$. Thereafter, non-adsorbed DNA was removed and competent cells were added. The results showed that the plasmid DNA lost approximately $88 \%$ of its transforming activity during the first $24 \mathrm{~h}$ (Fig. 3). This initial period of rapid inactivation (rate $0.037 \mathrm{~h}^{-1}$ ) was followed by a period of slower 
Table 2. Release of plasmid DNA from P. stutzeri JM302 (pS|1) and uptake by competent $P$. stutzeri BA155 cells in non-sterile soil microcosms

\begin{tabular}{|c|c|c|c|}
\hline \multicolumn{2}{|c|}{ Experiment } & \multirow{2}{*}{$\begin{array}{c}\begin{array}{c}10^{9} \times \text { Frequency of } \\
\text { His } \\
\text { in counts } \\
\text { mean } \pm \mathrm{SD} ; n=3-6)\end{array} \\
2.0 \pm 0.6 \dagger\end{array}$} & \multirow{2}{*}{$\begin{array}{l}\text { Percentage } \mathrm{Sm}^{\mathrm{R}} \text { cells } \\
\text { among His }{ }^{+} \text {cells } \\
\text { (colonies tested) }^{*} \\
\text { ND }\end{array}$} \\
\hline I. & (a) No donor cells added & & \\
\hline & (b) Donor cells added $\ddagger$ & $29 \pm 11+\|$ & $27(129)$ \\
\hline \multirow[t]{3}{*}{ II. } & Donor cells frozen/thawed $\$$ & & \\
\hline & (a) -DNase I & $78 \pm 47$ & $21(246)$ \\
\hline & (b) + DNase Ig & $3 \cdot 6 \pm 2 \cdot 4 \|$ & $<5(19)$ \\
\hline
\end{tabular}

$* \mathrm{Km}^{\mathrm{R}}$ and $\mathrm{LacZ}^{+}$colonies growing on M7P (non-selected markers) were streaked on LB-glucose agar containing streptomycin; all Sm${ }^{\mathrm{R}}$ clones tested $(n=24)$ had a plasmid indistinguishable from pSI1 in restriction analysis. ND, not determined.

$\dagger \|$ Differences significant $(P<0 \cdot 05)$; the differences between experiment II(a) and experiments $\mathrm{I}(\mathrm{a})$ and II (b), respectively, were $0.05<P \leqslant 0.08$.

$\ddagger 3 \cdot 2 \times 10^{10}$ viable count $(0 \cdot 7 \mathrm{~g} \text { soil })^{-1}$.

$\$$ Two freeze-thaw cycles followed by washing the microcosms with soil extract before competent BA155 was added (for details see Methods).

9 Cells were incubated in soil in the presence of DNase $\mathrm{I}$ at $23^{\circ} \mathrm{C}$ for $2 \mathrm{~h}$ before addition of competent BA155 cells.

inactivation $\left(0.001 \mathrm{~h}^{-1}\right)$. After $3 \mathrm{~d}, 3 \%$ of the initial transforming activity of pSI1 DNA was still detectable in the non-sterile soil. After prolonged incubation $(5 \mathrm{~d})$, the relative transformation frequency $(1 \%)$ detected was in the range of the spontaneous reversion frequency. Inactivation was probably due to nucleolysis of pSI1 DNA. In other studies using the same soil it was shown that $\left[{ }^{3} \mathrm{H}\right]$ thymidine-labelled DNA added to microcosms was degraded by DNases indigenous to the soil, eventually leading to acid-soluble material (Blum et al., 1997).

\section{Release of pSI1 DNA from cells in the soil}

The question was addressed of whether plasmid transfer by transformation can proceed between $P$. stutzeri strains in the soil. Such a process would require two steps, DNA release from donor cells and subsequent uptake of the DNA by competent recipient cells. Donor cells were incubated in the soil microcosm for $2 \mathrm{~h}$ which was then washed to remove suspended cells and nonadsorbed DNA, and subsequently charged with competent cells. The $\mathrm{His}^{+}$transformation frequency was significantly $(P \leqslant 0.05)$ higher than the frequency of spontaneous $\mathrm{His}^{+}$reversion (Table 2, expt I). Similar results were obtained at a lower donor titre $\left(6 \times 10^{8}\right.$ viable count per microcosm; data not shown). Among the $\mathrm{His}^{+}$transformants, a fraction was also $\mathrm{Sm}^{\mathrm{R}}$ and contained pSI1 (Table 2). In another experiment, the microcosm with the donor cells was frozen and thawed (Table 2, expt II). This treatment killed most $(87 \%)$ of the donor cells in the microcosm. The frequency of $\mathrm{His}^{+}$ transformants was at a level similar to that of experiments without freezing (Table 2, expts I and II). The results suggest that plasmid DNA was released from cells in the soil, adsorbed to particulate soil material and subsequently taken up by competent BA155 cells. Two observations confirmed that the transfer of the plasmid in this system occurred by transformation: (i) pSI1 was detected in a fraction of the $\mathrm{His}^{+}$transformants and (ii) the frequency of $\mathrm{His}^{+}$counts was reduced to the level of spontaneous reversion after DNase I treatment (Table 2).

\section{DISCUSSION}

It has been shown here that natural transformation of the soil organism P. stutzeri JM300 by extracellular chromosomal and plasmid DNA occurred in a nonsterile brown earth microcosm (Table 1). Most experiments were performed with a plasmid (pSI1) containing a region of homology to the $P$. stutzeri genome. The use of a genetic marker on the homologous sequence greatly enhanced the otherwise poor transformation of $P$. stutzeri by RSF1010 and its derivatives such as pKT210 (see also Carlson et al., 1984), and allowed the sensitive detection of transformation events in the soil microcosm. Several features of pSI1 transformation in the soil microcosm were very similar to those of pSI1 transformations under standard broth conditions: (i) the transformation frequencies were at the same levels (Figs 1 and 2); (ii) the dependence of transformation frequencies on amounts of plasmid DNA followed a first order reaction in both systems; (iii) the fraction of plasmid-containing $\mathrm{His}^{+}$transformants was comparable in broth and in soil; (iv) transformant formation in the soil over time paralleled the rate of transformation in broth (see Lorenz \& Wackernagel, 1990). Apparently, the plasmid DNA bound on soil particles was readily 
available for uptake by competent cells in the non-sterile soil.

The high transformation frequencies by chromosomal and plasmid DNA in the non-sterile soil were unexpected because DNase activity produced by microorganisms indigenous to the brown earth has been shown to degrade DNA added to the soil (Blum et al., 1998) and was thought to inhibit transformation. From the results presented here it appears that the DNase activity was not high enough to prevent transformation during the period of incubation of competent cells in DNA-loaded soil ( 2 to $4 \mathrm{~h}$ ). However, the transforming activity of the DNA declined gradually during prolonged incubation (Fig. 3). Nevertheless, after $3 \mathrm{~d} 3 \%$ of the initial transforming activity was still detectable in the soil. Other studies employing Southern transfer hybridization indicated that large DNA fragments (Blum et al., 1998) and also plasmids (S. A. E. Blum, M. G. Lorenz \& W. Wackernagel, unpublished) were present in the three soils studied, including the soil used here for up to $10 \mathrm{~d}$ after DNA was added. Probably pSI1 DNA or fragments thereof were present and perhaps transformation-active after $5 \mathrm{~d}$; unfortunately the transformation frequency determined was at the limit of detection. In studies employing purified soil components, including sand, clay minerals and material from groundwater aquifer, DNA was shown to be protected from rapid nucleolytic degradation by binding to the mineral surfaces (summarized in Lorenz \& Wackernagel, 1994; Paget \& Simonet, 1994). In an extension of these studies to different non-sterile soils it was recently established that in fact the fraction of DNA binding to soil particles persisted for long periods, whereas the DNA remaining non-adsorbed was completely converted to acid-soluble material by DNases indigenous to the soils within $24 \mathrm{~h}$ (Blum et al., 1998). Thus, rapid binding to surfaces has been suggested as the mechanism of escape of DNA from rapid degradation in natural soil. As shown here, DNA bound on natural soil particles is available to competent cells of $P$. stutzeri for transformation (Figs 2 and 3). Previous studies showing efficient uptake by $P$. stutzeri cells of DNA bound on quartz sand (Lorenz \& Wackernagel, 1990), clay, humic acids or sterilized soil particles (Paget \& Simonet, 1997) or marine sediment (Stewart et al., 1991) are in accord with the results obtained here. Whether DNA uptake in soil at the solid/liquid interface is a general phenomenon has to be proven. Other competent soil bacteria like B. subtilis and Acinetobacter calcoaceticus have also been shown to take up DNA adsorbed on sand, clay minerals and groundwater aquifer material (Lorenz \& Wackernagel, 1994; Paget \& Simonet, 1994).

Transfer from donor to recipient cells by transformation in the soil was demonstrated (Table 2). Apparently plasmid DNA was released from the donor cells which may have occurred by lysis or by secretion. High molecular mass DNA is released into growth media from several bacteria, including $P$. stutzeri (for a review, see Lorenz \& Wackernagel, 1994). The results presented here suggest that $P$. stutzeri JM300 can exchange genes by transformation in its natural habitat, the soil. A variety of abiotic and biotic factors have been suggested to influence transformation in soil (Stotzky, 1989). Among these are soil texture and structure. In recent experiments employing $A$. calcoaceticus added to sterilized soil microcosms, transformation frequencies differed up to 1000 -fold between two different soils. The high clay content in one of the soils was thought to stabilize the transforming DNA by adsorption to the mineral and hence favour transformation (Nielsen $e t$ al., 1997). The water content of soil could also be a critical factor for transformation. Movement of cells is required for their access to sites where transforming DNA is bound. This may be more promoted in water-saturated soil (the condition simulated in the present experiments), such as after heavy rainfall, ice melt or irrigation, than in water-limited soil with isolated microhabitats (see Stotzky, 1989). Another critical point of whether gene exchange by transformation may occur in soil is the development of competence of cells. This requires appropriate environmental conditions with regard to $\mathrm{pH}$, temperature, specific ions and available nutrients (Lorenz \& Wackernagel, 1994). Studies with P. stutzeri JM300 in vitro and in soil extract suggest that natural conditions like growth-limiting concentrations of nutrients could be conducive to the development of competence. Further experiments are necessary to explore under which conditions transformable bacteria would develop competence in non-sterile soil.

The work was supported by the Bundesminister für Bildung, Wissenschaft, Forschung und Technologie and the Fonds der Chemischen Industrie.

Arber, W. (1995). The generation of variation in bacterial genomes. J Mol Evol 40, 7-12.

Bagdasarian, M., Lurz, R., Rückert, B., Franklin, F. C. H., Bagdasarian, M. M., Frey, J. \& Timmis, K. N. (1981). Specificpurpose plasmid cloning vectors. II. Broad host range, high copy number, RSF1010-derived vectors, and a host-vector system for gene cloning in Pseudomonas. Gene 16, 237-247.

Blum, S. A. E., Lorenz, M. G. \& Wackernagel, W. (1997). Mechanism of retarded DNA degradation and prokaryotic origin of DNases in non-sterile soils. Syst Appl Microbiol 20, 513-521.

Canosi, U., Iglesias, A. \& Trautner, T. A. (1981). Plasmid transformation in Bacillus subtilis: effects of insertion of Bacillus subtilis DNA into plasmid pC194. Mol Gen Genet 181, 434-440.

Carlson, C. A., Pierson, L. S., Rosen, J. J. \& Ingraham, J. L. (1983). Pseudomonas stutzeri and related species undergo natural transformation. J Bacteriol 153, 93-99.

Carison, C. A., Steenbergen, S. M. \& Ingraham, J. L. (1984). Natural transformation of Pseudomonas stutzeri by plasmids that contain cloned fragments of chromosomal deoxyribonucleic acid. Arch Microbiol 140, 134-138.

Cohan, F. M. (1995). Does recombination constrain neutral divergence among bacterial taxa? Evolution 149, 164-175.

Doyle, J. D., Stotzky, G., McClung, G. \& Hendricks, C. W. (1995). Effects of genetically engineered microorganisms on microbial 
populations and processes in natural habitats. Adv Appl Microbiol 40, 237-287.

Dubnau, D. (1991). The regulation of genetic competence in Bacillus subtilis. Mol Microbiol 5, 11-18.

Dubnau, D. (1993). Genetic exchange and homologous recombination. In Bacillus subtilis and Other Gram-positive Bacteria: Biochemistry, Physiology, and Molecular Genetics, pp. 555-584. Edited by A. L. Sonenshein, J. A. Hoch \& R. Losick. Washington, DC: American Society for Microbiology.

Goodman, A. E., Marshall, K. C. \& Hermansson, M. (1994). Gene transfer among bacteria under conditions of nutrient depletion in simulated and natural aquatic environments. FEMS Microbiol Ecol 15, 55-60.

Holmes, D. S. \& Quigley, M. (1981). A rapid boiling method for the preparation of bacterial plasmids. Anal Biochem 114, 193-197.

Kokjohn, T. A. (1989). Transduction: mechanism and potential for gene transfer in the environment. In Gene Transfer in the Environment, pp. 73-97. Edited by S. B. Levy \& R. V. Miller. New York: McGraw-Hill.

Lopez, P., Espinosa, M., Stassi, D. L. \& Lacks, S. (1982). Facilitation of plasmid transfer in Streptococcus pneumoniae by chromosomal homology. J Bacteriol 150, 692-701.

Lorenz, M. G. (1998). Horizontal gene transfer among bacteria in soil by natural genetic transformation. In Microbial Interactions in Agriculture and Forestry. Edited by N. S. Subbarao \& Y. R. Dommergues. New Delhi: Oxford and IBH Publishing Co (in press).

Lorenz, M. G. \& Wackernagel, W. (1987). Adsorption of DNA to sand and variable degradation rates of adsorbed DNA. Appl Environ Microbiol 53, 2948-2952.

Lorenz, M. G. \& Wackernagel, W. (1990). Natural genetic transformation of Pseudomonas stutzeri by sand-adsorbed DNA. Arch Microbiol 154, 380-385.

Lorenz, M. G. \& Wackernagel, W. (1991). High frequency of natural genetic transformation of Pseudomonas stutzeri in soil extract supplemented with a carbon/energy and phosphorus source. Appl Environ Microbiol 57, 1246-1251.

Lorenz, M. G. \& Wackernagel, W. (1992). Stimulation of natural genetic transformation of Pseudomonas stutzeri in extracts of various soils by nitrogen or phosphorus limitation and influence of temperature and $\mathrm{pH}$. Microb Releases 1, 173-176.

Lorenz, M. G. \& Wackernagel, W. (1994). Bacterial gene transfer by natural genetic transformation in the environment. Microbiol $\operatorname{Rev~58,~563-602.~}$

Lorenz, M. G. \& Wackernagel, W. (1996). Mechanisms and consequences of horizontal gene transfer in natural bacterial populations. In Transgenic Organisms. Biological and Social Implications, pp. 45-57. Edited by J. Tomiuk, A. Sentker \& W. Wöhrmann. Basel, Boston, Berlin: Birkhäuser-Verlag.

Lorenz, M. G., Aardema, B. W. \& Wackernagel, W. (1988). Highly efficient genetic transformation of Bacillus subtilis attached to sand grains. J Gen Microbiol 134, 107-112.

Lorenz, M. G., Meyer, B., Wittstock, M., Graupner, S. \& Wackernagel, W. (1998). Selective DNA uptake and DNA restriction as barriers to horizontal gene exchange by natural genetic transformation in Pseudomonas stutzeri JM300. In Horizontal Gene Transfer. Edited by M. Syvanen \& C. Kado. London: Chapman and Hall (in press).
Lynch, J. M. (1982). Limits to microbial growth in soil. J Gen Microbiol 128, 405-410.

Maynard Smith, J., Dowson, C. G. \& Spratt, B. G. (1991). Localized sex in bacteria. Nature 349, 29-31.

Maynard Smith, J., Smith, N. H., O'Rourke, M. \& Spratt, B. G. (1993). How clonal are bacteria? Proc Natl Acad Sci USA 90, $4384-4388$.

Mazodier, P. \& Davies, J. (1991). Gene transfer between distantly related bacteria. Annu Rev Genet 25, 147-171.

Nielsen, K. M., van Weerelt, M. D. M., Berg, T. N., Bones, A. M., Hagler, A. N. \& van Elsas, J. D. (1997). Natural transformation and availability of transforming DNA to Acinetobacter calcoaceticus in soil microcosms. Appl Environ Microbiol 63, 1945-1952.

Paget, E. \& Simonet, P. (1994). On the track of natural transformation in soil. FEMS Microbiol Ecol 15, 109-118.

Paget, E. \& Simonet, P. (1997). Development of engineered genomic DNA to monitor the natural transformation of $P$ seudomonas stutzeri in soil-like microcosms. Can J Microbiol 43, 78-84.

Sambrook, J., Fritsch, E. F. \& Maniatis, T. (1989). Molecular Cloning: a Laboratory Manual, 2nd edn. Cold Spring Harbor, NY: Cold Spring Harbor Laboratory.

Solomon, J. M. \& Grossman, A. D. (1996). Who's competent and when? Regulation of natural genetic competence in bacteria. Trends Genet 12, 150-155.

Stewart, G. J., Sinigalliano, C. D. \& Garko, K. A. (1991). Binding of exogenous DNA to marine sediments and the effect of DNA/ sediment binding on natural transformation of Pseudomonas stutzeri strain ZoBell in sediment columns. FEMS Microbiol Ecol 85, 1-8.

Stotzky, G. (1989). Gene transfer among bacteria in soil. In Gene Transfer in the Environment, pp. 165-222. Edited by S. B. Levy \& R. V. Miller. New York: McGraw-Hill.

Stotzky, G. \& Babich, H. (1986). Survival of, and genetic transfer by, genetically engineered bacteria in natural environments. $A d v$ Appl Microbiol 31, 93-138.

Stotzky, G., Devanas, M. A. \& Zeph, L. R. (1990). Methods for studying bacterial gene transfer in soil by conjugation and transduction. Adv Appl Microbiol 35, 57-169.

Taddei, F., Matic, I. \& Radman, M. (1995). cAMP-dependent SOS induction and mutagenesis in resting bacterial populations. Proc Natl Acad Sci USA 92, 11736-11740.

Thomas, C. M., Wellington, E. M. H., Diaz-Orejas, R. \& Espinosa, M. (1994). Molecular biology and ecology of gene transfer and propagation promoted by plasmids. Microbiology 140 , 1799-1801.

Tiedje, J. M., Colwell, R. K., Grossman, Y. L., Hodson, R. E., Lenski, R. E., Mack, R. N. \& Regal, P. J. (1989). The planned introduction of genetically engineered organisms: ecological considerations and recommendations. Ecology 70, 298-315.

Travisano, M., Vasi, F. \& Lenski, R. E. (1995). Long-term experimental evolution in Escherichia coli. III. Variation among replicate populations in correlated responses to novel environments. Evolution 49, 189-200.

Received 7 July 1997; revised 22 August 1997; accepted 3 October 1997. 